\title{
Purchasing Intention of Historical Storytelling Products : A Study Focusing on Socially Responsible Consumption
}

\author{
Hiju Yoon ${ }^{1}$ and Jiyoung Yoon ${ }^{2 *}$ \\ ${ }^{1}$ Fashion Industry and Consumer Studies Department of Ewha Womans University, \\ Seoul, Korea \\ ${ }^{2 *}$ Graduate School of Education, Ewha Womans University, Seoul, Korea \\ lyoonhiju0121@gmail.com, ${ }^{2 *}$ graceyoon928@ewha.ac.kr
}

\begin{abstract}
The purpose of this research is to identify participant's purchasing motive of historical storytelling product in terms of socially responsible consumption. In-depth interview on female students in 20 s was conducted based on semi-structured questions built on Miller's social-cognitive model of social justice and commitment. Participants were told to state every experience and meaning of it in purchasing process. Interviews were recorded and transcribed in order to analyze the content using Giorgi's phenomenology methodology. This study provided insights of how historical storytelling is attached to a product or a brand and how it affects socially responsible purchasing motive. It was also meaningful to figure out how changing trend is reflected in socially responsible consumption. Limitations and implications of historical storytelling products could be used as marketing method in the future.
\end{abstract}

Keywords: History, historical storytelling, socially responsible consumption, purchasing intention, product storytelling, phenomenology, live experience research 


\section{Introduction}

As modern consumers have expanded their power over market and society through daily consumption (Mohr et al., 2001), the interest of political consumerism is heightening. Consumers consistently participate in society by purchasing particular product or refuse to purchase in order to lead a change in society as they want (Barcellos et al., 2014). In other words, consumers are aware of social responsibility when purchasing, not only acting in needs of personal necessity (Yoon and Yoon, 2020).

'Meaning out consumption' has appeared in a new form of consumption which is in line with political consumerism as also being an expression of political and social belief. A newly coined-term 'Meaning out consumption', a compound word of 'meaning' and 'coming out', includes boycotting brand using unethical practices or actively consuming products of socially responsible corporate (Sooyeon, 2019).

Political consumerism within historical issue also appears in diverse aspects (Kang, 2019). While people expressed their opinions by protest for political and social issues in the past, people nowadays demonstrate their idea through consumption (Sooyeon, 2019). Purchasing intent of Chinese consumers has decreased on account of Japan's distortion of history textbooks (Kang, 2019). Market share of Japanese corporates in Korea has also dramatically decreased due to Japan's distortion of history textbooks, Japan's sovereignty claim on Dokdo, and Japanese Prime Minister's visit to the Yasukuni shrine (Lee and Lee, 2005). As social network services (SNSs) such as Instagram invigorates, consumer boycott using SNS is increasing one after another (Sooyeon, 2019). According to 'A Phenomenon Analysis of Japan Boycott', mention of Japan boycott in SNS exceeds 1 million times which implies large scale of consumer boycott and growing strength of civic engagement. These are the cases of exercising purchasing vote for boycott based on one country's 'history'. In addition, in fact socially responsible consumption on historical aspect has increased in Korea (Yoon, 2019). It is considered as 'buycott', a consumer participation such as patronizing corporate with desirable conduct of business and solving social problems through consumption (Park, 2019). A typical example of historical storytelling brand MARYMOND has shown growth rate over $200 \%$ every year since 2015 and achieved \$9.7billion in 2017. This brand sheds new light on the victims of Japanese military sexual slavery (known as 'Comfort women') by using design and ideas of actual victims of one's will (Kang, 2018). 'Heeum' bracelet, also known as brand supporting comfort women, reached $\$ 1.3$ billion in 5 years (Kim, 2014). A Korean startup 'ZOEN' achieved $879 \%$ of targeted sale in 20 days by crowd funding sweatshirt of 264(lee yuk sa - a Korean independent activist and a writer who fought for Korea's independence against Japanese colonial rule) (Lim, 2019).

According to previous studies, many existing studies of socially responsible consumption are conducted in a wide range although socially responsible 
consumption can be separated into various fields such as history, environment, human rights, economy and so on. Moreover, it is difficult to find a study to link historical storytelling products and social responsibility consumption, which have recently been mentioned in interest (Yoon and Yoon, 2020). However, several studies have already included 'boycott' and 'buycott' under the same category of political such as Zorell (2018), Bossy(2014), Hoffmann \& Huuter(2012), and Holzer (2006) (Park, 2019). But still, studies conducted on socially responsible consumption by purchasing historical storytelling products are hard to find.

Therefore, this study is conducted to determine purchasing of historical storytelling product and brand in terms of socially responsible consumption, Miller et al.'s (2009) social-cognitive model of social justice interest and commitment was considered as the basis criteria of the study since ultimate purpose of socially responsible consumption is to achieve social justice (Cheon and Min, 2015).

To understand the purchasing motive of historical storytelling product in depth, qualitative research method was used which is appropriate to study motive or intent inherent in an individual (Song, 2015).

\section{Literature review}

Subsections are classified under two large groups: A. influential factors on consumer's purchasing motive such as socially responsible consumption and product storytelling and B. measure of purchasing motive like social-cognitive model of social justice interest and commitment and Giorgi's (1970) phenomenology methodology.

\subsection{Socially responsible consumption}

Starting with Benkrowitz's study on Socially Conscious Consumer(SCC) (Kim, 1994), research on socially responsible consumption came up as an issue after Anderson and Cunningham's discussion about increasing consumers who are interested in social or environmental issue (Cheon and Min, 2015). They defined consumers with social consciousness as "consumers who practice collective behaviour that enhances social and environmental welfare or make market provide such product or service". Also You \& Sim (1998) socially conscious consumer as "consumer who try to use their purchasing power to change society or consider the functions of personal consumption in a public level". Following researches also suggested definition of socially conscious consumer.

Before 1990s, studies on socially responsible consumption were focused on ecofriendly consumption (Kim, 1994). Socially responsible consumption studies have entered a new phase in 1995, distinguishing environment friendly consumer and consumer who pursuit societal change, naming the latter group as 'socially responsible consumer' (Cheon and Min, 2015). Since then, consumer's social responsibility was defined as a conscious choice of consumption built on a personal 
conviction including actions such as boycott, buycott and suggesting opinion (Kim et al, 2017).

'Meaning out consumption', a compound word of 'meaning' and 'coming out', is also in the line with socially responsible consumption, known as an expression of personal preference and social belief by consuming (Kim et al, 2017). Meaning out consumption is involved in diverse areas related to society such as environment, history, human rights, animal rights and so on. Consumers interested in animal rights pay much more money to buy products from corporate maintaining better feeding environment for animals. Message fashion became popular among consumers who want to directly deliver one's political and social preference. Growth of social network services promoted socially responsible consumption even more by consumers enjoying to display self-expressive consumption on their SNS (Sooyeon, 2019).

Nowadays, socially responsible consumption includes social issues caused by mass consumption society likewise environment, human rights, labor, poverty, culture and so on. This means individual consumption is interrelated with consumption for contemporary humankind in a perspective of socially responsible consumption. Therefore, modern meaning of socially responsible consumption refers to not only buying socially conscious product but putting social responsibility into a purchasing action by one's principle (Hong and Song, 2010).

\subsection{Product storytelling}

Storytelling, an oldest form of communication, is defined as a diverse formed articulation of human's basic desire to share one's thought with (Yoon and Yoon, 2020). Effects of storytelling are as follows: it can create want to know particular subject, provide new kinds of knowledge, and build up new communication method in situation of using various expressions (Sin et al., 2014).

Product or brand storytelling are not quite different from the concept of basic storytelling. Product storytelling derives from attempt to communicate with customers by using the story of the product for marketing. Consumers get familiar with the product by naturally learning the story of the product. This leads to an interaction between consumer and product or brand rather than just advertising certain product (Sin et al., 2014).

For this reason, storytelling is used as a means of delivering corporate value (Yoon and Yoon, 2020). It also helps create consumer's interest, reinforce product and brand identity, differentiation, and maintain relationship with consumer (Seo, 2016).

In addition, Seo (2016) suggested that effective product storytelling has a positive impact on consumers' purchasing intentions. Through the story reflected in the brand, consumers experience the process of discovering their identity which makes them identify themselves with the brand using product story as a medium. Consumers regard the product or the brand they selected more meaningfully 
because it can serve as a means of self-expression. As a result, consumers get to pay lot of money to buy the brand's product they prefer. From advanced research, effective storytelling of the product or brand seem to have positive effect on consumer's purchasing intention. This study included product storytelling as a key factor that could possibly have influence on the purchasing motive of historical storytelling products.

\subsection{Social-cognitive model of social justice interest and commitment}

Social cognitive theory, a theoretical background of social-cognitive model of social justice interest and commitment, is about how to enhance psychosocial dynamics that affect human behavior and behavioral change. Human behavior in this theory is explained in which change occurs within complex effect of cognitive, behavioral, and environmental factor. Major concepts stressed in social cognitive theory are environment, behavioral capability, situation, observational learning, reciprocal determinism, reinforcement, expectations, self-efficacy, and self-control. Based on this concept, Miller et al. (2009) set up components of social justice like selfefficacy, outcome expectation, interest, commitment, social support and barrier in order to analyze interest and action related to social justice (Cheon and Min, 2015).

Social justice efficacy is a belief about perception ability of performing social justice action. This factor is categorized into an individual level (e.g. selfrecognition and monitoring), interpersonal level(e.g. leading others' participation in social inequality), community level(e.g. promoting social interest), and institutional/political level(e.g. resisting against discrimination-involved policy and custom). Higher social justice efficacy means the possibility of getting interested in social justice performance or practicing it increases. And Social justice outcome expectation refers to an expectation to a positive outcome from social justice activity while social justice efficacy is a capacity to actually perform such activity. It is predicted that the more one trusts about the success of the outcome, interest and practice of social justice activity will increase. Also, social justice interest means preference or indifference toward social justice activity while social justice commitment is an actual performance of planned social justice behavior. Lastly, social support and social barrier are contextual components of social justice activity which raise facilitation and hinderance of the activity. Cheon and Min (2015) asserted direct influence of social support and social barrier on social justice commitment, while insisted about the indirect influence of social support and barrier through self-efficacy.

Based on the fact that socially responsible consumption is proceeded from actualizing consumer own's justice (Cheon and Min, 2015; Song, 2015), this study will focus on socially responsible purchasing motive of consumers by using socialcognitive model of social justice interest and commitment.

\subsection{Phenomenology methodology}


In the field of social science study, qualitative approach is well used to demonstrate subjective emotions which are closely related to human life. Qualitative research method can be divided into several fields under various theoretical basis, but most of all, categorized into phenomenological study, symbolic interactionism, analytics, ethnography and etc (Choi, 1993). In fact, phenomenology may be appropriate to describe about human's experience and his nature within a holistic approach. This is because the ultimate purpose of the phenomenological method is to understand human being and to explain the essence of object's behavior and cognition (Omery, 1983).

Phenomenology is method of describing live human experience for holistic approach to human nature (Kim et al., 1999). Especially, Giorgi (1970) developed the descriptive phenomenology focusing on tracing the essence of phenomenon revealed from consciousness. Researchers can distinguish the true essence of experience in between changing consciousness and understand participant's thinking process (Koo, 2018).

The processes of Giorgi and Giorgi's (2003) phenomenology methodology are organized in 5 steps.

First, identify natural meaning unit of expression about one's experience as the way participant said. Secondly, figure out theme that represents participant's experience. Third, determine focal meaning of what particular experience meant to the participant by specifying theme in researcher's word. Fourth, make a situated structural description about the meaning of experience in researcher's point of view. Lastly, create a general structured description about the meaning of experience (Kim et al., 1999). Therefore, this study was conducted by using phenomenological method.

\section{Method}

\subsection{Survey}

To carry out this study, we conducted three expert meetings consisting of professors of consumer department, researchers and clothing researchers, and improved the validity and reliability of the study. Investigation on approach method about the research topic and advanced research were held on the first meeting on September 9th, 2019. The second meeting was focused on the applicability of the measurement method as an exploratory study on October 11th, 2019. Detailed verification of the semi-structured interview questions was also discussed by professors and researchers on November 8th, 2019.

Semi-structured interview questions were based on the outline of Cheon \& Min's (2015) study also using the categories of Miller et al. (2009). The original survey was formed to interview about social-justice behavior itself but re-organized considering the subject 'socially responsible consumption related to historical storytelling product'. For instance, one of the original questions about 'social 
support' was 'Family of mine will support my socially responsible consumption' and evaluated in a ten-point scale. On the other hand, in this study, interviewees were asked questions such as 'What were the reactions of people around you about your purchasing of historical storytelling products'. These questions were modified to meet the purpose of this study and let interviewees to speak freely about their thoughts.

After this, consumers who have purchasing experience of historical storytelling product were surveyed considering the research purpose. According to the study that behavior towards socially responsible enterprise has positive correlation with re-purchasing motive (Kang and Kim 2014) consumers who have multiple purchasing experiences of historical storytelling product were prioritized as an interviewee. Also, female students in 20 s were chosen as participants in two reasons. Firstly, lots of consumers in 20s were actively participating in meaning out consumption which is in similar vein to socially responsible consumption (Sooyeon, 2019). Also, most of the historical storytelling products were produced to support female rights likewise donation to Japanese military sexual slavery, so-called 'comfort women' (Yoon and Yoon, 2020).

In order to secure the ethics of research, participant recruitment went through the following process. The users of the 'V-Day Project' in Seoul, the capital city of South Korea, were chosen as the participants to collect representative cases. The recruitment was conducted in online considering participants' realistic status. ' $\mathrm{V}$ Day Project' is a community site of consumers with historical awareness. Study participants were recruited through social network services after stating the purpose of the study.

Also, guidelines were informed in this site beforehand for people's participation. The guidelines included the purpose and the background of this study and the notice that there will be no disadvantages even if the participant quit during the interview. The guidelines also provided information about online points that can be used in the community. Personal information such as gender, age, occupation, purchasingd brand, number of purchasings were collected through the study. The participants were told that personal information that is not relevant to the study purpose and can specify one individual will not be collected. The fact that collected personal information were kept in USB with a locking device, only the person in charge of the study has access to the collected information, and that the documents related to the study including interview questionnaires will be totally discarded with shredder after storing for 3 years since the research end-point under 「Article 15 of the Bioethics and Safety Act $\rfloor$ (Yoon, 2019). 6 participants were selected through the process above. Characteristics of the participants are as shown in Table 1.

Table 1: General attributes of the participants 


\begin{tabular}{|c|c|c|c|}
\hline & Gender & Age & $\begin{array}{c}\text { The number of purchasings of } \\
\text { historical storytelling products }\end{array}$ \\
\hline A & Female & 22 & 4 \\
\hline B & Female & 23 & 4 \\
\hline C & Female & 24 & 8 \\
\hline D & Female & 23 & 5 \\
\hline E & Female & 23 & 8 \\
\hline F & Female & 22 & 2 \\
\hline
\end{tabular}

\subsection{Measurement}

In-depth interview was conducted for detailed description of participant's experience. This measurement was chosen because it seemed to be appropriate to understand personal and internal motive of the purchasing.

Interview was held in a café or E university in Seodaemun-gu, Seoul. The interview began with small talk to make participants feel comfortable and familiar with the situation. For interviewee's right, the purpose of the study was given before the actual interview and asked their intention to participate once again. Confidentiality and anonymity of personal information and the conversation was promised. Participants were also told that they are able to stop the interview if wanted.

Interview was conducted for two weeks from November 12th, 2019. Each of the interview lasted about 30 minutes each. Interview was recorded under permission of participants and later transcribed into a text.

After creating a comfortable atmosphere through small talks, the concept of historical storytelling product was explained with an image to the interviewees. After that, semi-structured interview was given to the participants asking in-depth question about the interrelation between historical storytelling product and socially responsible consumption. The order of the question was flexibly changed according to the conversation flow which helped participant to freely express their thoughts.

After the in-depth interview, the researcher repeatedly red the participants' statements and tried to understand the implying messages into clarified forms in order to demonstrate the meaning of the live experiences of the participants (Parse et al., 1985). The materials were organized by listening to the recording and after this, Giorgi's phenomenology methodology was used to identify participant's subjective and individual experience of purchasing historical storytelling product.

\section{Results}


This study was analyzed following the analysis process of qualitative study and categorization were done regarding to the concepts that are found during organization of the interview. Therefore, Giorgi's phenomenology methodology was used to identify participant's subjective and individual experience of purchasing historical storytelling product (Giorgi, and Giorgi, 2003).

Giorgi's (1970) descriptive phenomenology is acknowledged as the most reliable method to depict the essence of the form that appears from individual's thoughts. This method is more persuasive than other methods wherein it follows systematic analysis procedures. They descriptive phenomenology was set as a basic frame for analysis and detailed analysis was organized in 4 steps of 'overall recognition', 'identifying natural meaning unit', 'transforming into an academic term', and 'integrating modified meaning unit' (Giorgi, and Giorgi, 2003). By first step, there was an attempt to understand overall feeling and outline of the experience by repeatedly listening to audio material and reading transcribed text of the interview. The researcher took bracketing in order to eliminate any bias and understand the meaning of the word as it is. Secondly, natural meaning of the statement was identified by analyzing word, sentence and paragraph. The researcher tried to focus on the phenomenon of the research topic while figuring out the natural meaning unit.

Participants' statement went through a modifying process since it was expressed in various ways. After reviewing the statement again, interviewees' words were variated into academic expressions. If it is difficult to articulate in academic expression, terms and expressions that were able to understand in common-sense were used. 
Table 2: Analysis process example

\begin{tabular}{|c|c|c|c|}
\hline & \multicolumn{2}{|c|}{ Natural Meaning Unit } & Constituent \\
\hline $\begin{array}{l}\text { "I got to know there } \\
\text { are historical } \\
\text { problems through } \\
\text { these brands. I was } \\
\text { thankful to the brand } \\
\text { which introduces } \\
\text { historical issues, and } \\
\text { these products serve } \\
\text { as an effective means } \\
\text { to let others know } \\
\text { about the history. } \\
\text { This made me } \\
\text { purchasing again and } \\
\text { again." }\end{array}$ & $\begin{array}{l}\text { Got to know there are } \\
\text { historical problems } \\
\text { though these brands / } \\
\text { there are brand which } \\
\text { introduces historical } \\
\text { issues / she was } \\
\text { thankful to these brands } \\
\text { / these brands sell } \\
\text { products that serve as } \\
\text { an effective means to } \\
\text { let others know about } \\
\text { the history / this led her } \\
\text { to purchasing the } \\
\text { product again }\end{array}$ & $\begin{array}{l}\text { - She got to know } \\
\text { historical problems } \\
\text { through historical } \\
\text { storytelling brands } \\
\text { - She felt gratitude to } \\
\text { have opportunity to } \\
\text { learn about history by } \\
\text { these brands } \\
\text { - She regards these } \\
\text { products as an effective } \\
\text { way to inform about } \\
\text { the history } \\
\text { - This function made } \\
\text { her to buy the product } \\
\text { again }\end{array}$ & $\begin{array}{l}\text { - Better } \\
\text { understanding } \\
\text { of history } \\
\text { - Expecting } \\
\text { widespread } \\
\text { historical } \\
\text { awareness }\end{array}$ \\
\hline $\begin{array}{l}\text { "People around me } \\
\text { feel as if they're } \\
\text { talking about a } \\
\text { different world. Some } \\
\text { of them avoid such } \\
\text { issues. My mom also } \\
\text { regard history as a } \\
\text { sensitive issue and } \\
\text { does not want me to } \\
\text { talk about it. That } \\
\text { kind of words makes } \\
\text { me not to buy the } \\
\text { product." }\end{array}$ & $\begin{array}{l}\text { People around me feel } \\
\text { as if they're talking } \\
\text { about a different world } \\
\text { when having } \\
\text { conversation about } \\
\text { buying historical } \\
\text { storytelling products / } \\
\text { Some of people avoid } \\
\text { talking about historical } \\
\text { issue / My mom also } \\
\text { regard history as } \\
\text { sensitive issue / Mom } \\
\text { does not want me to } \\
\text { talk about historical } \\
\text { issue / She was going to } \\
\text { buy historical } \\
\text { storytelling product / } \\
\text { Mom's response makes } \\
\text { her not to buy the } \\
\text { product }\end{array}$ & $\begin{array}{l}\text { - People around her are } \\
\text { not familiar with } \\
\text { buying historical } \\
\text { storytelling products } \\
\text { - Some of people } \\
\text { around her avoids } \\
\text { talking about her } \\
\text { consumption } \\
\text { - Her mom shows } \\
\text { negative response to } \\
\text { her purchasing of } \\
\text { historical storytelling } \\
\text { products } \\
\text { - Negative response of } \\
\text { people around her } \\
\text { makes her refuse to buy } \\
\text { historical storytelling } \\
\text { products }\end{array}$ & $\begin{array}{l}\text { Abandoning } \\
\text { socially } \\
\text { responsible } \\
\text { consumption } \\
\text { due to negative } \\
\text { opinion from } \\
\text { others }\end{array}$ \\
\hline
\end{tabular}

Similar meaning units were classified into themes and re-categorized by their constituents. As a result, 2 categories, 7 topics, 12 sub-topics and structured meaning of each sub-topic were organized as Table 3. Especially, topics were determined using components of Miller et al. (2009), their social-cognitive model of social justice interest and commitment. 
Table 3: Result of the study

\begin{tabular}{|c|c|c|c|}
\hline Category & Topic & Sub-topic & Structured Meaning \\
\hline \multirow[t]{9}{*}{$\begin{array}{l}\text { Socially } \\
\text { Responsible } \\
\text { Consumption }\end{array}$} & Interest & Encounter & $\begin{array}{l}\text { Pre-existing interest in history } \\
\text { Group purchasing } \\
\text { Favorite celebrity's use of the product } \\
\text { Banner ads }\end{array}$ \\
\hline & \multirow[t]{2}{*}{$\begin{array}{l}\text { Commitmen } \\
\mathrm{t}\end{array}$} & $\begin{array}{l}\text { Purchasing } \\
\text { Experience }\end{array}$ & $\begin{array}{l}\text { Repeated purchasing behavior } \\
\text { Recommend purchasing to others } \\
\text { Lead group purchasing }\end{array}$ \\
\hline & & Purchasing Plan & $\begin{array}{l}\text { Complicated purchasing standard } \\
\text { comparing to the initial purchasing }\end{array}$ \\
\hline & \multirow[t]{2}{*}{$\begin{array}{l}\text { Self- } \\
\text { efficacy }\end{array}$} & Purchasing Reason & $\begin{array}{l}\text { Altruistic behavior } \\
\text { Donation and sponsorship system } \\
\text { Unique brand identity }\end{array}$ \\
\hline & & $\begin{array}{l}\text { Emotion after } \\
\text { Purchasing }\end{array}$ & $\begin{array}{l}\text { Self-satisfaction } \\
\text { Supportive self } \\
\text { Better understanding of history } \\
\text { Self-conscious consumption }\end{array}$ \\
\hline & \multirow[t]{2}{*}{$\begin{array}{l}\text { Outcome } \\
\text { Expectation }\end{array}$} & Personal expectation & $\begin{array}{l}\text { Quality, design, practicality of the } \\
\text { product }\end{array}$ \\
\hline & & Public expectation & $\begin{array}{l}\text { Widespread historical awareness } \\
\text { Social consensus of painful history } \\
\text { Increase support on the socially weak } \\
\text { Positive influences on society } \\
\text { (especially through SNS) }\end{array}$ \\
\hline & \multirow[t]{2}{*}{$\begin{array}{l}\text { Contextual } \\
\text { Factor }\end{array}$} & Social Support & $\begin{array}{l}\text { Appreciation and support from others } \\
\text { Dissemination of socially responsible } \\
\text { consumption }\end{array}$ \\
\hline & & Social Barrier & $\begin{array}{l}\text { Abandoning socially responsible } \\
\text { consumption due to negative opinion } \\
\text { from others }\end{array}$ \\
\hline \multirow[t]{3}{*}{ Storytelling } & Product & $\begin{array}{l}\text { Perception toward } \\
\text { Historical } \\
\text { Storytelling Product } \\
\end{array}$ & $\begin{array}{l}\text { Social responsibility } \\
\text { Incomparable competitiveness }\end{array}$ \\
\hline & \multirow[t]{2}{*}{ Brand } & Limitation & $\begin{array}{l}\text { Persisting transparent and ethical } \\
\text { business } \\
\text { Design limitations }\end{array}$ \\
\hline & & Expected goal & $\begin{array}{l}\text { Maintaining unique brand storytelling } \\
\text { Social responsibility }\end{array}$ \\
\hline
\end{tabular}

\section{Discussion}

This study is conducted to understand the purchasing motive of historical storytelling product from a standpoint of socially responsible consumption. Implication of the experience from the participants presented in the results will be discussed.

The experience of the interviewees could be classified into 5 categories; interest, commitment, self-efficacy, outcome expectation, and contextual factors. 
First of all, the motivation of being interested in historical storytelling products was not common among the participants, but different depending on individual circumstances. Banner ads and favorite celebrity's use of the specific product were one of the experiences that the participants were influenced. Pre-existing interest on history or socially responsible consumption also led participants to buy such products. There were also several participants who group purchasingd in conformity with their classmates. According to the researchers' statements, it can be seen that people become interested in historical storytelling products, influenced by reference group such as celebrities, teachers or friends.

Every interviewee had at least 2 times of purchasing experience. Also, some participants showed active commitment by promoting group purchasing in voluntary. In addition, every participant gave positive response in terms of repurchasing. One difference is that participants stated that they would consider more of design or functional aspects when purchasing again, although they mostly focused on social responsibility at the time of initial purchasing.

Moreover, it was able to understand the impact of self-efficacy on the purchasing of historical storytelling products by asking questions about the reason for purchasing and emotions after the purchasing. The motivation for the purchasing, which was commonly emphasized by the participants, was a donation and sponsor system that was connected to the purchasing of historical storytelling product. Participants also showed a belief that they could help others through purchasing and lead the society and participant herself to have a better understanding of the history. They also had confidence that this purchasing behavior will make them a better person. This result is consistent with 'self-efficacy', a belief in one's perceived ability which Miller et al. (2009) emphasized in areas of commitment or interest in socially responsible consumption.

The purchasing behavior of historical storytelling product led to an expectation of both private and public level. Participants talked about their personal expectations of the product such as better design or improvement of practicality. This means consumers who pursuit social responsibility consumption does not overlook other components and reconsider about the purchasing if the practicality or design lacks. Interviewees showed much more interest in social outcome expectation because they believed that it is possible to raise historical awareness through the purchasing behavior. Participant expressed their expectations of spreading social consensus about the painful history, hoping that this purchasing will positively impact on both past and present history. As well as historical aspect, participants had expectations of increased help for the socially disadvantaged. The form of help could mean a link between social contribution and historical storytelling brand or civic engagement(support) through better public awareness. Participants were also aware of the diffusion effect that SNS could have such as accelerating consumption trend of historical storytelling product or socially conscious mind itself. 
Lastly, contextual factors such as social support or social barrier had influence on the participant's purchasing. It is seemed that people's support for socially responsible consumption had a positive impact on purchasings. Participants felt appreciated when others praised about their consumption. Also, they recognized that they are the ones with good influence if others get interested or actually purchasing such products. However, negative reactions from people around them undermined their intention to buy. Skeptical response or criticism also made the participants feel skeptical about their purchasing. It is thought to be similar to Miller et al. (2009), their research that positive outcome expectation leads to interest or commitment of the socially responsible activity while negative outcome expectation brings the opposite result.

Thus, every participant emphasized on socially responsible meaning that historical storytelling has. They assessed that purchasing desire has increased as the social aspect of historical storytelling and the drive of socially responsible consumption worked together. This also led participants to positively evaluate the market competitiveness of historical storytelling product and brand. Among various ways to contribute to the society, historical storytelling product enables social contribution just by consuming a product.

However, participants stressed that since the historical storytelling brand presents the image of social enterprise, it should be operated transparently in areas such as donations and social contribution activities. Necessity of increased amount of donation and risen percentage of social contribution activities was raised. Moreover, participants strongly emphasized that the historical figures or events should not be excessively used for ethical issues. As it is a brand based on the historical storytelling, it is expected to continue its clear brand storytelling of 'history' and fulfill its responsibility as a social enterprise which promotes participants' socially responsible consumption.

\section{Conclusion and limitations}

This study was conducted by using Giorgi's (1970) phenomenological qualitative research method, interviewing 6 users of socially conscious online community in depth about historical storytelling products. As observing the participants in 5 different fields using Miller et al. (2009), their theory, the reason of getting interested in historical storytelling products were various among participants. However, all participants showed self-efficacy that they can lead to change by purchasing likewise donation, social contribution, attitude change and this selfefficacy actually affected their purchasing. Also, participants showed expectation related to social change in common such as widespread historical awareness, empathy and help for painful history. Moreover, it is found that participant's purchasing behavior is influenced either positively or negatively through social support or barrier. 
It is meaningful that this study closely looked into subdivided category of 'history' other than comprehensive approach which were normally done by existing studies of socially responsible consumption.

Nonetheless, it was possible to understand the participant's live experience through in-depth interview based on a phenomenological approach. By conducting this study through qualitative research, we were able to focus more on the experiences more on the experiences and perceptions of consumers rather than on global level that can be found out through quantitative research. In other words, through this study, we were able to understand the overall thinking process from purchasing motive to ultimate purchasing of consumers purchasing historical storytelling products. This means it was able to approach to 'the essence of the behavior', known as the aim of the phenomenology. The study results could be used to achieve better outputs for not only purchasing historical storytelling products but companies if using self-efficacy, outcome expectations, and interaction of social supports which affects the motivation of socially responsible consumption

It is also relevant that this was an extended study of consumer's purchasing intention by additionally analyzing the impact of the 'product's storytelling'. This study was to observe in diverse aspects socially responsible consumption and product storytelling, not just only studying about purchasing motive of a specific product. It is expected that there will be various fields of study about socially responsible consumption in the future based on this research.

However, this study still has limitations even though it has certain implications.

This study was conducted only on six adult females in their 20 s who were interested in historical consumption. Although sufficient interviews were conducted through in-depth questions, it may not be enough to say that the participants represent Korean women in their 20s. Further study is expected to be conducted with larger population of male/female participants in balanced ratio. Besides gender, it may be even more meaningful to expand the range of the age with consumption power and conduct comparative research according to generation. It is also hoped that this study will allow us to conduct comparative research with consumers in other countries beside South Korea. This approach may possibly be able to provide generalized analysis of socially responsible consumption behavior within historical storytelling products, not limited to an individual or certain ethnic.

In addition, participants of this study are those belonging to the online community who are interested in consuming socially responsible products, that are already more actively interested in consuming socially responsible products than ordinary consumers. It is expected that further studies will be focused on more generalized samples. Quantitative research may carry out more generalized implications by standardizing the data. Despite some of these limitations, this study has significance as a research in relatively early stage. It is anticipated that the results of this study will be effectively used in the marketing practice of corporates 
as well as achieving academic meaning of socially responsible consumption.

\section{References}

Barcellos D., Martia D., Caio M. T., and Jonas C. V. (2014). Personal values associated with political consumption: An exploratory study with University Students in Brazil. International Journal of Consumer Studies, 38(2), 207-216.

Cheon, H., and Min, M. K. (2015). The path analysis of the related variables affecting socially responsible consumption: Application of social justice interest and commitment model. Consumer Policy and Education Review, 11(1), 25-49.

Choi, Y. H. (1993). Soomoonsa, Nursing Qualitative Research, 1993.

Giorgi, A. P. (1970). Psychology as a Human Science, New York : Harper \& Row.

Giorgi, A. P., and Giorgi, B. M. (2003). The Descriptive Phenomenological Psychological Method. Qualitative Research in Psychology, Expanding Perspectives in Methodology and Design, 243-273.

Hong, Y. G., and Song, I. S. (2010). The concept and practice areas of ethical consumption. Consumer Policy and Education Review, 6(4), 91-110.

Kang, J. S. (2018). How social venture marymond's sales has increased almost upon 10 billion dollars?. Fashionbiz, https://www.fashionbiz.co.kr/article/view.asp?cate=1\&sub_num=22\&idx=167355

Kang, M. S., and Kim, Y. S. (2014). The effect of people's attitude on social enterprises: The adjustment effect of ethical consumption intentions, 28(6), 479-498.

Kang, T. (2019). Influences of Antecedents to Consumers' Japanese Brand Boycott Attitude and Intention. The Japanese Modern Association of Korea, 195-212.

Kim, B. H., Kim, K. Ja., Park, I. S., Lee, K. J., Kim, J. K., Hong, J. J., Lee, M. W., Kim, Y. H., Yoo, I. Y., and Lee, H. Y.. A Comparison of phenomenological research methodology - Focused on Giorgi, Colaizzi, Van Kaam Methods -. Journal of Korean Academy of Nursing, 29(6), 1207-1220.

Kim, J. G. (2014). Heeum Bracelet, Helping Comfort Women, Hit the Jackpot. Maeil Economy, https://www.mk.co.kr/news/society/view/2014/10/1289022/ 
Kim, K. D. (1994). Analysis of socially responsible consumers' profile. Annual Bulletin of Seoul Health, 14(1), 273-287.

Kim, N. D., Jeon, M. Y., Lee, H. E., Lee, J. Y., Kim, S. Y., Choi, J., Lee, S., and Seo, Y. H..(2017). Miraebook Publishing Co., Trend Korea 2018, 2017.

Koo, J. H. (2018). A qualitative study on prospective librarians' library practicum experiences: Applying Giorgi's descriptive phenomenological method. Journal of the Korean Biblia Society for Library and Information Science, 29(4), 269-296.

Lee, H. S., and Lee, G. S. (2005). The effects of animosity toward Japan and ethnocentrism on product satisfaction and repurchasing intension. Korea Distribution Association, 10(4), 69-87.

Lim J. (2019). [Trend \& Review]: How products built on history gained its popularity. Eroun net. http://www.eroun.net/news/articleView.html?idxno=6061.

Miller, M. J., Sendrowitz, K., Connacher, C., Blanco, S., de la Peña, C. M., Bernardi, S., and Morere, L. (2009). College students' social justice interest and commitment: A social-cognitive perspective. Journal of Counseling Psychology 56(4), 495-507.

Mohr, L. A., Webb D. J., and Harris K. E. (2001). Do consumers expect companies to be socially responsible? The impact of corporate social responsibility on buying behavior. The Journal of Consumer Affairs, 35(1), 45-72.

Omery, A. (1983). Phenomenology: A method for nursing research. Advanced in Nursing Science, 5(2), 49- 63.

Park, M. H. (2019). Study on conceptualization and scale development of political consumption. Journal of Consumer Studies, 30(2), 117-146.

Parse, R. R., Coyne A. B., and Smith M. J. (1985). Bowie: Brady communications comp., Nursing Research: Qualitatiave Method.

Seo, S. H. (2016). The influence of brand storytelling types on the structural relationships among brand consciousness, brand identification, image elaboration, brand image, attitude toward brand. Advertising Research, 31-63.

Sin, H. R., Kim, Y. M., and Yoon, S. J. (2014). Effects of storytelling technique and product involvement on advertisement attitude, brand attitude and purchasing intention. Journal of Korea Culture Industry, 14(2), 53-59. 
Song, S. R. (2015). The Lebenswelt's topology and the alltagsgeschichte: a phenomenological study for overcoming and reconstructing of historicism (1); based on the ontological nature of mediation of place. Korean hermeneutics study, 36, 313-360.

Sooyeon O. (2019). Meaning-out trend. Excellence Marketing for Customer, 53(11), 55-61.

Yoon, H., and Yoon, J. (2020). A qualitative research on the motives of purchasing historical storytelling products. Journal of Humanities Research and Methodology, 1(1), 1-6.

Yoon, J. (2019). A study on an eco-friendly product purchasing process using expanded theory of planned behaviour, Ph. D. Dissertation. Ewha Womans University, South Korea, 1-136.

Yoon, T. S. (2019). 100 Days of Japan Boycott... Largest Scale with High Spontaneity. Hankookilbo. https://news.v.daum.net/v/NgnW4RyKcb?f=p.

You, D. R., and Sim, M. Y. (1998). A study on the socially responsible attitude and behavior of consumer. Family and Environment Research, 36(11), 1-17. 